Article

\title{
Reassessing the Role of Shared Mobility Services in a Transport Transition: Can They Contribute the Rise of an Alternative Socio-Technical Regime of Mobility?
}

\section{Lisa Ruhrort}

Wissenschaftszentrum Berlin für Sozialforschung (WZB), Reichpietschufer 50, 10785 Berlin, Germany; lisa.ruhrort@wzb.eu

Received: 2 September 2020; Accepted: 30 September 2020; Published: 7 October 2020

Abstract: Recent years have seen a proliferation of platform-based "shared mobility services" (SMS) such as car-, bike-, and e-scooter-sharing in many cities in Germany and around the world. At the same time, these services have become the subject of intense debates: Are they replacing private car travel, thus contributing to sustainable mobility in cities? Or are they drawing users away from public transit and cycling while obstructing public space? From the perspective of sustainable mobility politics, it seems far from clear which role these new services could play in transitioning to a less car-centric mobility system. While a number of potential effects and ensuing governance issues of shared mobility services (e.g., regarding questions of equitable access, data governance, the role of public versus private actors) have already been studied, this article explores the role of shared mobility services (SMS) in triggering system dynamics and feedback loops in the context of sustainability transitions. The article connects questions regarding the sustainability effects of "shared mobility services" with the role of "push" measures to reduce private car traffic in cities. Using a theoretical framework from socio-technical transitions research and from the sociology of technology, it describes the recent growth of shared mobility services in Berlin as an example of the upscaling dynamics of socio-technical niche innovations. Drawing on a series of workshops with mobility service providers and representatives of public authorities, it analyses the potential for conflict as well as for coalition-building between service providers and public authorities. Based on the theoretical concept of the role of feedback loops and windows of opportunity for transitions, it shows how the market growth of shared mobility services has added momentum to an already ongoing political debate over the legitimate use of public space in Berlin. Against this backdrop, the article discusses how growing numbers of car-, bike-, and e-scooter-sharing vehicles could open up windows of opportunity for re-distributing space away from private cars. The article concludes that supporting and regulating SMS will be key to steering their growth in the direction of sustainability.

Keywords: transport policy; sustainable mobility; shared mobility services; multi-level perspective; socio-technical systems

\section{Introduction}

Since the release of the latest IPCC report [1] and the first indications of climate change becoming visible in central Europe, the urgency to steer the transport sector in the direction of ecological sustainability has been recognized more and more broadly. The German government has set itself the goal to reduce transport emissions by 40 percent by 2030 [2]. As scenario studies have shown, this goal cannot be reached by switching to zero emissions vehicles alone; climate neutrality also requires a modal shift from private cars to more efficient modes of transport and an overall reduction in travel demand $[3,4]$. In this sense, a sustainability transition in the transport sector equals a disruption of 
current mobility structures and trends [5]. As many studies have shown the private car is firmly entrenched at the center of an established "socio-technical regime" [6], which is comprised of highly profitable structures of industrial production, a car-centered landscape of infrastructures and spatial structures, as well as a set of social practices and cultural patterns that favor car use over other modes.

While path dependencies in the mobility system are strong, recently a number of trends have emerged in many large European cities that seem to question the dominance of the private car. In Germany, in a number of cities, the modal share of car traffic has stagnated or declined slightly [7], and there are some signs that "push" strategies to reduce car traffic are gaining popular support [8]. Berlin is an example of how the role of different transport modes has increasingly become re-politicized [9]. Pressured by grassroots initiatives, the city has recently decided to implement policy measures that redistribute space away from cars to other modes and other uses. At the same time, former niche innovations in the form of car-sharing, bike-sharing, and e-scooter-sharing have seen remarkable growth [10]. However, while the importance of public transport, cycling, and walking for sustainable mobility politics is widely accepted, the role of these "shared mobility services" (SMS) in a future sustainable mobility system is more contested. The relatively sudden appearance of new car-, bike-, and e-scooter-sharing services confronts local and national authorities with a range of new governance challenges [11] —in Germany as well as in many countries around the world [12]. While some see these services as important elements of a "multioptional mobility system" [13], others caution that they might draw consumers away from public transport, walking, and cycling without reducing car traffic [14].

This article uses the term "shared mobility services" (SMS) to sum up car-, bike- and e-scooter-sharing services. These services can be defined as "product-service systems" [15], which "[...] combine an asset (a car) and a service which gives customers access to this asset instead of ownership" [16]. While Schaefers uses this definition for car-sharing, it can be applied to bicycles or other vehicles accordingly. The term "shared mobility services" is not unproblematic. "Sharing" implies elements of not-for-profit collaborative use as well as interactions between users [17], while the services that are in focus here are commercial services for short term vehicle rentals. Nonetheless, the terminology of "bike-sharing" and "car-sharing" is well established in the literature as well as in practice [18]. This is why short term rental services will be summed up here as "shared mobility services" (SMS). This article focusses on short term rental services that are currently available in Germany. This focus does not include passenger transport services such as Uber, or so called "ride-pooling" services such as MOIA or CleverShuttle, which are also currently active in a number of German cities. This is due to the fact that passenger transport services in Germany are subject to a different legal framework than short term rental services, making comparisons between the two segments difficult.

A range of studies has looked into user groups, usage patterns, and potential effects of SMS, as well as the ensuing governance issues (e.g., regarding questions of equitable access, data governance, the role of public versus private actors, etc., $[11,19])$. This article adds to this research by exploring a formerly neglected dimension: the role of SMS in triggering system dynamics in the context of sustainability transitions. While many studies focus either on usage patterns or on the immediate effects of SMS on the transport system, this article connects the debate on SMS with the debate around "push" measures to reduce private car traffic [20] and thus with the "politics of mobility" surrounding the issue of public space in cities. This perspective stresses that the role of different elements of sustainability transitions, such as rising levels of cycling, rising support for car-restraining policy measures, and growing demand for new mobility services, cannot be understood in isolation but need to be assessed as parts of complex system dynamics.

Using a theoretical framework from socio-technical transitions research and from the sociology of technology, I describe the recent growth of SMS in Berlin as an example of the upscaling dynamics of socio-technical niche innovations. I describe how the sudden market entry of numerous new mobility services in 2018 and 2019 confronted public authorities with a challenge to either hinder or encourage their growth. I draw on a series of workshops with SMS providers and representatives of public 
authorities to describe how this situation created potential for conflict as well as for coalition-building between service providers and public authorities. Using the theoretical framework of the role of feedback loops and windows of opportunity for transitions, I show how the market growth of SMS added momentum to an already ongoing political "street fight" [21] over the legitimate use of public space in Berlin. Against this backdrop, the article discusses how growing numbers of car-, bike-, and e-scooter-sharing vehicles could open up windows of opportunity for re-distributing space away from private cars. The article concludes that supporting and regulating SMS will be key to steering their growth in the direction of sustainability.

The remainder of this article is structured as follows: Section 2.1 lays out a theoretical framework, which conceptualizes the growth of SMS as the beginning of a breakthrough process of niche innovations. This framework stresses the role of politics and the regulatory context for the breakthrough of innovations. Section 2.2 outlines the ongoing debate over the role of SMS in reducing the modal share of private car traffic. Section 3.1 describes some characteristics of the socio-technical system of mobility in Germany, while Section 3.2 zooms in on the example of Berlin. I describe the context of recent transport policies and discourses in the city as well as the market growth of SMS with a focus on the years 2018 and 2019. Section 4.1 describes the methodological approach and scope of the workshop series with SMS providers, while Section 4.2 outlines key results of the workshop discussions. Section 5 discusses the findings from Berlin using the theoretical framework developed in Section 2.1. Section 6 draws conclusions, points out the limitations of this paper, and formulates questions for future research on the role of SMS in a sustainable mobility transition.

\section{Theoretical Framework and State of Research}

\subsection{Theoretical Framework: Models of Socio-Technical Change}

\subsubsection{Multi-Level-Model of Socio-Technical Transitions}

The multi-level perspective (MLP) of socio-technical transitions is a useful starting point for studying the role of SMS in sustainability transitions. The MLP was developed as a theoretical framework for conceptualizing and studying transition processes of socio-technical systems [22]. This perspective differentiates between three different levels: niche, regime, and landscape. At the center of this concept is the idea that socio-technical systems such as the automobile system are stabilized in the form of a socio-technical regime. This type of regime is marked by high (dynamic) stability and strong path dependencies, meaning that radical changes are difficult to achieve. Despite this high stability, socio-technical regimes can come under pressure from two sides [22]. On the one hand, the broader societal environment, called "landscape", constantly changes and can threaten the stability of regime structures. On the other hand, niche actors try to challenge the regime by introducing innovations. It is often difficult for these to break through into mass markets, because the institutional structures of the dominant regime are designed to support the dominant technological solutions [23]. Under certain circumstances, multi-level dynamics can open up "windows of opportunity", which allow niche innovations to gain momentum and threaten the given socio-technical regime. This can lead to changes in regime structures or to the establishment of a new socio-technical regime. While originally the MLP was developed to study socio-technical change in general, research on sustainability transitions (STR) introduces a normative component by asking how transitions to more sustainable socio-technical systems can become possible [24].

\subsubsection{Complexity: Feedback Loops, Tipping Points, and Windows of Opportunity}

The MLP has proven useful to studying transition processes in the transport sector [6,23]. It helps to explain why changes such as a modal shift from car traffic to other modes are highly challenging; they do not merely depend on individual decisions but involve challenging the structures of the socio-technical regime. This regime includes cultural patterns and collective orientations as well as 
powerful social actors who are invested in the dominant technology [6]. This perspective is closely related to Urry's [25] concept of a multidimensional "system of automobility". This perspective stresses that path dependencies in the transport system strongly favor a continuous reproduction of the status quo, making radical change such as a transition to lower modal shares of the private car seem inherently difficult and improbable. Against this backdrop, Urry stresses that attempts to change the "automobile system" in a linear way will probably remain unsuccessful. Instead, "the current car-system could not be disrupted by linear changes but only by a set of interdependent changes occurring in a certain order that might move, or tip, the system into a new path." [25].

Put another way, this means that many different trends and developments will have to occur at the same time in order to disrupt the normal reproduction of system structures. In this context, Watson [26] stresses the importance of positive or negative feedback loops, which occur between different elements of socio-technical systems, e.g., between changes in social practices of mobility and the acceptability of transport policy measure that favor alternatives to car use. Ruhrort [5] describes a recent example of such positive feedback loops between mobility practices and mobility politics in the transport sector: Rising levels of cycling and a revival of cycling culture in many German cities have enabled grassroots initiatives to successfully demand more space for cycling. With political pressure mounting, infrastructural changes can now be implemented, which in turn can help to further stabilize the growth of cycling demand, and so on. According to Urry [25], the complex interplay between different factors can culminate in "tipping points": "Tipping points involve three notions: that events and phenomena are contagious, that little causes can have big effects, and that changes can happen not in a gradual, linear way but dramatically in a moment when the system switches" [25] (p. 33). Against this theoretical background, it becomes clear that transitions to sustainability are inherently conflicted and "messy" processes. This may be especially true for the mobility sector which, in comparison to the energy sector, is marked by a more diverse field of actors [6].

\subsubsection{Upscaling, Network Building, and Breakthrough}

Focusing on the complexity of socio-technical change processes makes it clear that sustainability transitions cannot be conceived of as linear processes of "progress". Following Urry's perspective, a large scale reduction of car use will not be achieved by linear steps such as a gradual improvement of cycling infrastructure or public transport (PT). Instead, large scale change will likely require a "messy" process in which a number of different factors intertwine to disrupt the status quo. In this context, Köhler et al. [24] stress that processes of upscaling, breakthrough, and acceleration are currently beginning in a number of sectors, which challenge STR to move from a focus on niche actors and niche developments to more complex fields of actors of different scale and power. While one of the core concepts of STR has focused on "strategic niche management" [27], sustainability transition research in the transport sector now needs to develop concepts that describe how political actors attempt to manage upscaling and breakthrough processes of former niche innovations.

As former niches grow bigger, they are increasingly confronted with the institutional structures of the established regime. These are often designed to support the established technological solutions and can form barriers against the upscaling of alternatives [28]. To scale up and to break through into the mainstream, it becomes increasingly important for niche actors to try to influence their environment in order to create more favorable conditions-often through changes of the regulatory framework or the distribution of key resources. In the language of the social construction of technology (SCOT), successful breakthrough of innovations requires the intertwining of social, political, and technological factors in a "seamless web" [22]. This is why actors have to engage in "heterogeneous engineering" [29] if they want their innovation to succeed. STR, therefore, " $[\ldots]$ is concerned with interactions between various actors in the development and diffusion of innovations [ ... ] Innovation is understood as arising from actions and interactions in social contexts, rather than from an intrinsic technical or economic logic" [22]. 


\subsubsection{Mobility Politics in Transition: The Key Role of Access to Public Space}

As Sengers [30] has pointed out, the MLP focuses on the power struggles between "the forces of stability against the forces of change"- be it particular technical innovations, social practices, or sets of actors. When former niche innovations move into the mainstream, the power struggles between the status quo and the "contenders" become more openly political [28]. In the upscaling phase, creating "protective niches" [27] for innovations is no longer enough: The actual "rules of the game" need to be changed, and key resources (such as access to public space) need to be redistributed to make room for the new. For the transport sector, this means that STR increasingly needs to focus on the social in the technological but also on the political in the technological. In the language of socio-technical transitions, "network-building" or "coalition-building" become important to enable the breakthrough of innovation [22]. This perspective places the upscaling of (former) niche innovations such as caror bike-sharing in the context of political strategies to achieve sustainability transitions. It stresses that fundamental change, such as a broad shift from private car ownership to SMS, will not be driven by technology alone, but will need to be pushed by policies that directly target the structures of the dominant regime ([5], with regard to the energy sector [28]).

In the transport sector, one of the key structures stabilizing the current regime lies in the use of public space. If politics is seen to revolve around the question of "who gets what, when, and how" [31], then mobility politics strongly revolves around who gets access to public space. As many scholars of the history of transport have shown, the dominance of car traffic was achieved by massive changes of spatial settings, especially in cities [32]. Henderson [32] has shown that the "politics of mobility" [33] have long been enacted as a "street fight", in which the automobile has established its dominance by claiming almost exclusive access to public space [34]. Establishing a transport system with substantially less car use would make it necessary to reverse this process and give space back to alternative transport modes [21]. This is why transport planning often stresses the necessity to combine "push" as well as "pull" measures $[5,35,36]$. This means that alternatives to private car travel need to become more attractive (pull), and at the same time, regulatory and spatial settings need to be changed to make car use less attractive (push).

Stressing the role of "push" measures underlines the political nature of sustainability transitions. While pure "pull" strategies can often be implemented with relatively low political costs, a push and pull strategy often leads to intense political debate [5,37]. Using the example of Copenhagen, Henderson and Gulsrud [21] argue that a transition to a more sustainable transport system cannot be conceived as a mere "win-win"-process, particularly when it comes to access to public space [38]: To substantially increase the share of alternative modes of transport, be it cycling, walking, public transport, or potentially SMS, space has to be taken away from private car traffic. This is why, when new mobility services scale up, the question of re-distribution of public space becomes imminent: Will e-scooters share road space with pedestrians, cyclists, or cars? Will car-sharing fleets get designated parking spots or use the same space as private cars? These questions come to the forefront of political debate.

\subsubsection{Transformation Dynamics: Analytical Versus Normative Concepts}

In the process of upscaling and acceleration, contenders will try to influence policy actors to initiate changes of the established regulatory and institutional structures in their favor [27]. Policy actors in turn will try to influence market actors to make them change their services in line with political goals. In this process, former niche innovations can become the focus of explicit political debate. Different types of actors can use this as an opportunity to create (formal or informal) arenas of negotiation and communication between public authorities and new market players. The "contenders" may try to win over public authorities but also the general public to support their cause [27]. They can also attempt to form (formal or informal) alliances-between each other or with city authorities or other actors.

Importantly, the "contenders" who challenge a given socio-technical arrangement are not always driven by ecological intentions. Especially in the acceleration phase, contenders are often large companies whose most pressing concern is to develop a functioning business model [24]. In this 
phase, socio-technical transition dynamics can increasingly shift from struggles between ecological niche innovations and regime actors to struggles for market shares between old and new players in a capitalist economic system [39]. Niche actors engaging in network-building can become merged with powerful business interests engaging in lobbying to achieve favorable changes of the regulatory framework. From the perspective of sustainability research, this means that upscaling will often increase the "messiness" of transition processes: With big industry players entering a transition arena, the distinction between "friends" and "foes" of sustainable change becomes increasingly blurred.

This is why, in studying upscaling processes, it becomes increasingly important to distinguish between different types of transformation dynamics [24]. Brand and Wissen [39] identify an analytical perspective on transformation that stresses that capitalist societies are constantly marked by transformation dynamics, with phases of relative stability being the exception rather than the norm. The current dynamics of digitization are a prominent example. They put pressure on the existing regime structures, forcing established actors to adapt (e.g., by moving from automobile manufacturer to car-sharing provider), while also generating opportunities for new players to enter the market. Yet this type of transformation dynamic does not necessarily lead in the direction of ecological sustainability. Normative concepts of transformation (or sustainability transition), by contrast, ask under which circumstances socio-technical systems can be changed in the direction of sustainability [39].

The theoretical framework developed here makes it possible to see SMS as (former) niche innovations that are currently entering a phase of accelerated market growth and upscaling. It also stresses that in this phase, former niche innovations start to claim substantial resources, especially in the form of access to public space. At the same time, the sustainability merits of these innovations become increasingly contested. This is why transition dynamics in this phase become more openly political. The following section outlines some key elements of the state of research regarding the role of SMS for sustainable mobility.

\subsection{Assessing the Role of SMS in Sustainable Mobility Transitions}

Scenarios of sustainable mobility tend to agree that the modal share of traditional public transport as well as of cycling and walking need to be raised and the modal share of private car travel reduced [40]. By contrast, the role of car-, bike-, and scooter-sharing for sustainable mobility is much more contested [12]. The rise of shared mobility services has been driven by different factors. In Germany, the development of SMS started with the introduction of car-sharing in the late 1980s [5], which gained traction in the early 2000s and was accompanied by the introduction of bike-sharing. Both remained niche innovations, until a new phase brought the widespread use of digital mobile communication technology in the late 2000s. Large OEMs entered the market and introduced free floating car-sharing services (FFCS). A third wave began around 2017 with the internationalization of free floating bike- and later e-scooter-sharing services (FFBS, FFES). Both Chinese and US-based companies made their market entry in Germany, quickly followed by a number of competitors from Germany and other European countries [12]. Free floating services use the advances in mobile apps, routing, and GPS technology to scale up fleets of bikes and scooters in many cities around the world. With their growing visibility, the potential effects and the role of SMS in a sustainable mobility system have increasingly become the subject of scientific studies. Three broad strands of the debate can be identified.

One strand of research focuses on user groups, usage patterns, and the effects of SMS on the transport system and on ecological sustainability more generally. These studies often use standardized surveys to describe the user groups of SMS and to study the purposes and motives for which the services are being used. Many also focus on the question of to which extent SMS replace car-trips or car-ownership or, on the contrary, replace public transport, cycling, or walking trips, with mixed results. For example, while a number of studies have shown that station-based car-sharing services lead to a net reduction in car ownership, the evidence for FFCS is more mixed: Becker et al. [41] found that free floating car-sharing is mostly used for non-regular trips and that six percent of car-sharing 
users forego vehicle ownership due to the availability of the service. Shaheen et al. [42] found similar results for North America, finding that FFCS contributes to a reduction of cars on the road. In Germany, Kopp et al. [43] studied the mobility behavior of FFCS-users in comparison to a control group and concluded that FFCS can play an important role in stabilizing multimodal mobility patterns in urban areas. On the other hand, Hülsmann et al. [44], using a longitudinal study design, found no negative effects of FFCS membership on public transport use but also no reduction in users' overall transport-related $\mathrm{CO}_{2}$ emissions or car ownership. The authors concluded that FFCS itself cannot reduce the number of cars on the road, but can play an important complementary role to PT, cycling, and walking once cities decide to enact "push" measures to reduce private car use.

Similar results have been found regarding FFBS services. Ma et al. [45] summed up the literature on the modal shift impact of bike-sharing services, finding that in most studies, only a relatively small number of bike-sharing trips replaces car trips. Rather, bike-sharing plays a role in complementing public transport and walking [46]. Research on e-scooter-sharing schemes is still limited due to the novelty of the schemes. A study by the city of Portland found that e-scooters were used by both locals and visitors to the city and that between 34 and 48 percent of e-scooter trips replaced car trips [47]. By contrast, a study by Krier et al. [48] showed that in Paris, only eight percent of e-scooter trips replaced car trips. In a lifecycle analysis, Hollingsworth et al. [49] found that today's generation of e-scooters comes with substantial ecological costs. Overall, the literature on the immediate impacts of SMS on transport mode choice seems to suggest that SMS on their own will only have minor effects on car use in cities. Instead, studies tend to show that the impacts of SMS depend on their role as an element of transport policy strategies to reduce car use.

A second strand of research focuses on the potential of SMS as part of an integrated mobility system. One of the core concepts is "mobility as a service" (MaaS) [50]: "MaaS is a relatively recent and rapidly shifting concept associated with Smart Mobility and consists of a hybrid technological innovation combining ICT with a business model for delivering integrated access to transport services" [19]. The MaaS model "aims to provide seamless trips over one interface by combining different transport modes and services." [51] (p. 1). The most ambitious concepts include the bundling of different transport services into service packages for monthly payment [19], but often the term is used more broadly to describe "[ .. ] multi-modal mobility services, brokered via digital platforms connecting users and service operators" [19]. Importantly, the concept of MaaS is not by definition a normative ecologically-oriented concept. As critics have noted, the integration of different transport services via digital platforms could have positive effects by making PT more attractive, but they could also come with negative externalities [19]. One area of criticism is that most SMS, which form important complements to PT in MaaS-concepts, are offered by private profit-seeking companies. From this perspective, MaaS could open the door to a further privatization of the mobility sector [52]. Doherty et al. [11] point out that a shift towards an integrated "smart" mobility system including SMS might increase the power of large platform corporations, decrease equitable access to mobility by different groups of society, or inhibit local governments' access to crucial data. In this context, the authors stress the need to develop a regulatory framework to make new mobility services contribute to sustainability goals.

A third, sociologically-oriented, strand of research looks at the potential of SMS to foster a transition towards a "multioptional mobility culture" in which new social practices of mobility—such as combining different modes of transport-would break the dominance of the private car $[5,13]$. In the transition to a multioptional mobility culture, the role of public transport would change drastically from a "subaltern regime" [6] to the centerpiece of a new "multimodal regime" of mobility. Ruhrort [5] argues that SMS could function as "anchors" of such a new mobility culture by normalizing new social practices of mobility beyond private car ownership. By showing that alternative forms of organizing mobility are possible, they could help erode the "cultural hegemony" [53] of the private car. Again, many authors have pointed out the potential negative externalities of a future "multioptional" mobility system. Groth [54] criticizes that a shift to a multioptional mobility system could lead to a growing digital divide in mobility. Canzler et al. [13] stress that SMS can contribute to a cultural shift, 
but need to be integrated into a regulatory framework and transport policy strategies that drastically reduce private car travel in cities.

As the brief overview shows, the effects of SMS in the context of sustainable mobility transitions are the subject of a multifaceted debate. The market growth of most SMS as well as many MaaS-concepts is not ecologically motivated but is driven by a search for new business models based on digital technologies. The empirical studies mentioned above tend to show that, on their own, SMS tend to have only minor effects on car use. Yet from the perspective of STR, the question remains about what role SMS could play in triggering feedback loops and in opening windows of opportunity for sustainability-oriented transport policy. To explore this question, Section 3 focuses on the example of Berlin.

\section{Mobility and Mobility Politics in Germany: Cities as Birthplaces of an Alternative Mobility Regime?}

\subsection{Background: Structures of the Socio-Technical System of Mobility in Germany}

In 2019, the German government set itself the goal to reduce carbon emissions of the German economy to almost zero by the year 2050. For the transport sector, the goal is to reduce emissions by 40 percent by the year 2030 (in comparison to 1990 levels). As a number of scenario studies have shown, reaching this goal will make it necessary to shift demand from private cars to more resource-efficient modes and to reduce the overall demand of private car travel. Yet the general trend is going in the opposite direction. The transport sector in Germany continues to be on a growth path [55]. Schwedes [56] points out that the discord between climate goals and the actual development of real transport demand is unsurprising given that national transport policy in Germany has for decades been marked by a set of competing policy goals: increasing mobility as a prerequisite for economic growth and individual "freedom" on the one hand and mitigating or reducing the harmful side effects of transport (especially climate emissions and air pollution as well as other forms of environmental degradation) on the other: "The now hegemonic scientific transport discourse [in Germany, L.R.] [ ... ] follows the idea of a sustainable development through sustainable growth."(p. 17).

From the perspective of the MLP, the current system of passenger transport in Germany is clearly dominated by the automobile system. The number of cars is rising-from 47,000,000 in 2019 to $47,700,000$ in 2020 [57]. Currently, around 75 percent of all miles traveled are by car, and the number of vehicle miles traveled per day is rising [55]. Despite recent shifts of younger people towards less car-oriented behavior patterns, the overall patterns of transport demand in Germany have been marked by stability [14]. The dominant patterns of mobility demand are matched by the structures of production in the economic system. In 2019, more than 800,000 people were directly or indirectly employed in the production of automobiles [58]. Safeguarding the growth of the automobile industry is a central goal of the German federal government [59].

The multi-level perspective stresses that a given socio-technical regime is supported by a set of material and institutional structures including the design of spaces and infrastructures but also the regulatory framework [6]. In the case of transportation, these structures were often designed to support and enable the dominance of automobility [6,34]. From the perspective of the MLP, mobility politics need to be seen in the context of socio-technical regimes [28]. Transport policy actors and their goals are part of socio-technical regimes and often help to stabilize regime structures through political intervention. In this sense, the role of the government is not that of a neutral actor [39]. Instead, political strategies and goals are an expression of power relations in a given socio-technical system.

For Germany, a number of studies have recently shown how the legal framework of transport was shaped by the goal of fostering mass motorization and car traffic [60,61]. Hermann et al. pointed out how public space is increasingly dedicated to parking spaces for private cars-a development enabled by legally defining the parking of private vehicles as part of the "common use" ("Gemeingebrauch") of street space. Bracher et al. [62] pointed out that federal law has a strong position in the regulation of transport and limits the ability of cities to create parking regulations [63]. In this sense, the system of 
passenger transport in Germany is characterized by a dominant regime of automobility. A "subaltern regime" of public transport [6] as well as cycling and walking also play a major role in everyday mobility but are far less dominant in terms of their corresponding economic structures and political representation. As many scholars have remarked, transport policy in Germany has been marked by a "dualistic" strategy $[64,65]$. Transport policy on all federal levels tends to support the development of public transport and also cycling and walking while also supporting and fostering car mobility. In this sense, the priorities of transport policy in Germany, especially on the national level, correspond to the structures of a dominant regime of automobility and a subaltern regime of public transport.

\subsection{Cracks in the Regime: Beginning the "Street Fight" and the Rise of SMS in Berlin}

While the structures of the dominant mobility regime in Germany may appear hyperstable, some "cracks" [6] in the regime structure have recently begun to broaden. In many cities such as Berlin, Munich, or Cologne the modal share of car trips has stagnated or has been slightly reduced, the modal share of cycling has increased, public transport demand has stabilized, and new mobility services have emerged [7]. In Berlin, for example, the modal share of the car has been reduced from 30 percent in 2013 to 26 percent in 2018-mostly due to an increased share of cycling (from 13 to 18 percent), while PT and walking shares have been roughly stable. At the same time, public debate over transport policy has intensified in many cities. As Geels noted in 2012, cities have long been the only powerful actors in the field of transport policy with a genuine interest in reducing car traffic [6]. Driven by a number of different goals-mainly reducing negative impacts of car traffic on the quality of life, reducing noise and (local) pollution, and contributing to climate change mitigation, but also non-environmental goals such as improving traffic flows or supporting economic growth-many cities have explicitly set themselves targets to achieve more sustainable mobility development [66].

Recently, the efficient and equitable use of public space has come to the forefront of public debate in many cities. The excessive use of public space for storing private cars is increasingly becoming the subject of political debate, also regarding the legal framework of transport $[3,60]$. It is now widely acknowledged that the needs of cycling and walking should play an increasingly important role in transport planning. Thus, while the number of cars on the road continues to rise, there are some indications that the "cultural hegemony" [53] of the car in German cities is becoming increasingly contested. Berlin is one of the cities in which this trend has become more prominent. In 2016, the grassroots initiative "Referendum Initiative for Cycling" ("Volksentscheid Fahrrad") successfully collected almost 100,000 signatures to demand improvements of the cycling infrastructure [9]. Many of its demands were later signed into law by a newly elected left-wing and green party government in 2017: the Berlin Mobility Act [67]. This act sets the goal of improving conditions for public transport, cycling, and walking. A number of goals have implications for a re-distribution of public street space, e.g., the creation of protected bike lanes on important roads, re-designing dangerous junctions to make cycling safer, and creating a network of "cycling highways".

Two years after the law was passed, there are mixed opinions as to its efficacy [9]. In the course of the COVID-19-shutdown in early 2020, the state, together with a number of boroughs, decided to create a network of pop-up bike lanes [68]. The mobility act lent extra legitimacy to these interventions. A number of roads in the city center now have newly installed protected bike lanes, but an overarching plan for improving the cycling network is still being drafted. A central problem is that authority for transport planning is split between the federal state of Berlin and the local level of 12 individual "boroughs" (Bezirke). Especially the redistribution of parking spaces for cars is not in control of the state. While some criticize the lack of progress in implementation, the mobility act and the ensuing redistribution of public space can be seen as elements of the beginning of transport transition dynamics in Berlin and an expression of a re-politicization of the use of public space [9].

At the same time, Berlin also saw a proliferation of car-, bike-, and scooter-sharing services. The following section analyses the market growth of SMS in Berlin in the years 2018 and 2019. It draws on desk research to reconstruct the development of SMS in Berlin in the given time period. In the 
context of a joint publication, WZB and MFive together collected data on the development of SMS in large cities in Germany, focusing on the number of service providers, the different market segments, and the number of vehicles each provider deployed [10].

As Figure 1 shows, three free-floating bike-sharing services (FFBS) newly started operations in the city in the winter of 2017, followed by two more in the spring of 2018. By the beginning of 2019, some had disappeared again, but in the summer of 2019, new free-floating e-scooter services (FFES) (Figure 2) were introduced instead. Both of these "waves" were accompanied by heated debates in the local media. The car-sharing market (Figure 3) was also marked by the entry of a number of new services such as SIXT share and WeShare (the latter a subsidiary of VW AG) in 2019, as well as providers of peer-to-peer car-sharing platforms such as Turo and Ubeeqo. Moped-sharing was introduced in 2016 with two providers still being in the market in Berlin by 2020. As Figure 2 shows, by fall 2019, the number of shared mobility vehicles in Berlin reached around 40,000 (compared to roughly 1.2 million private cars [57] (Figure 4).

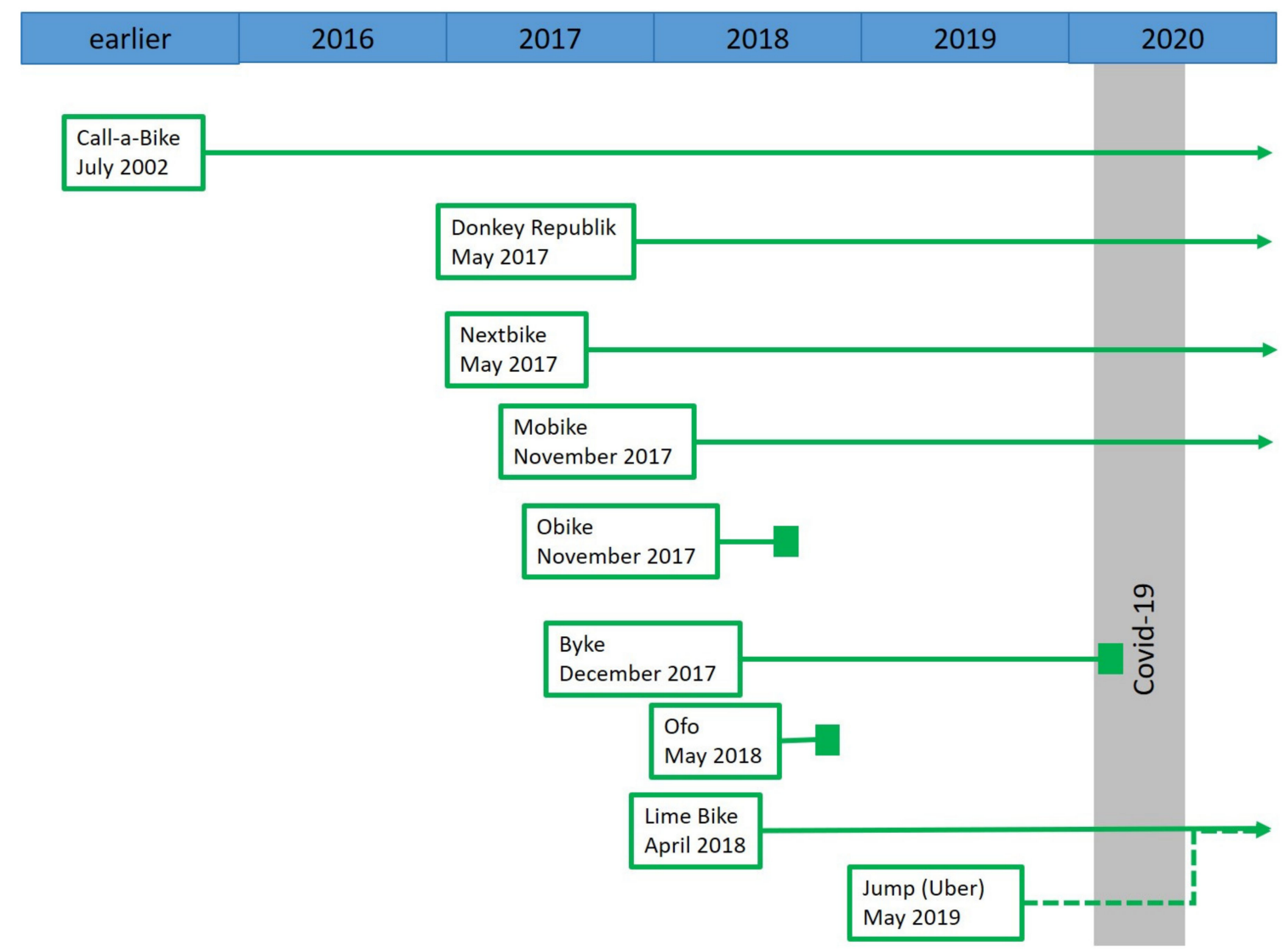

Figure 1. Market entry and exit of bike-sharing providers in Berlin. 


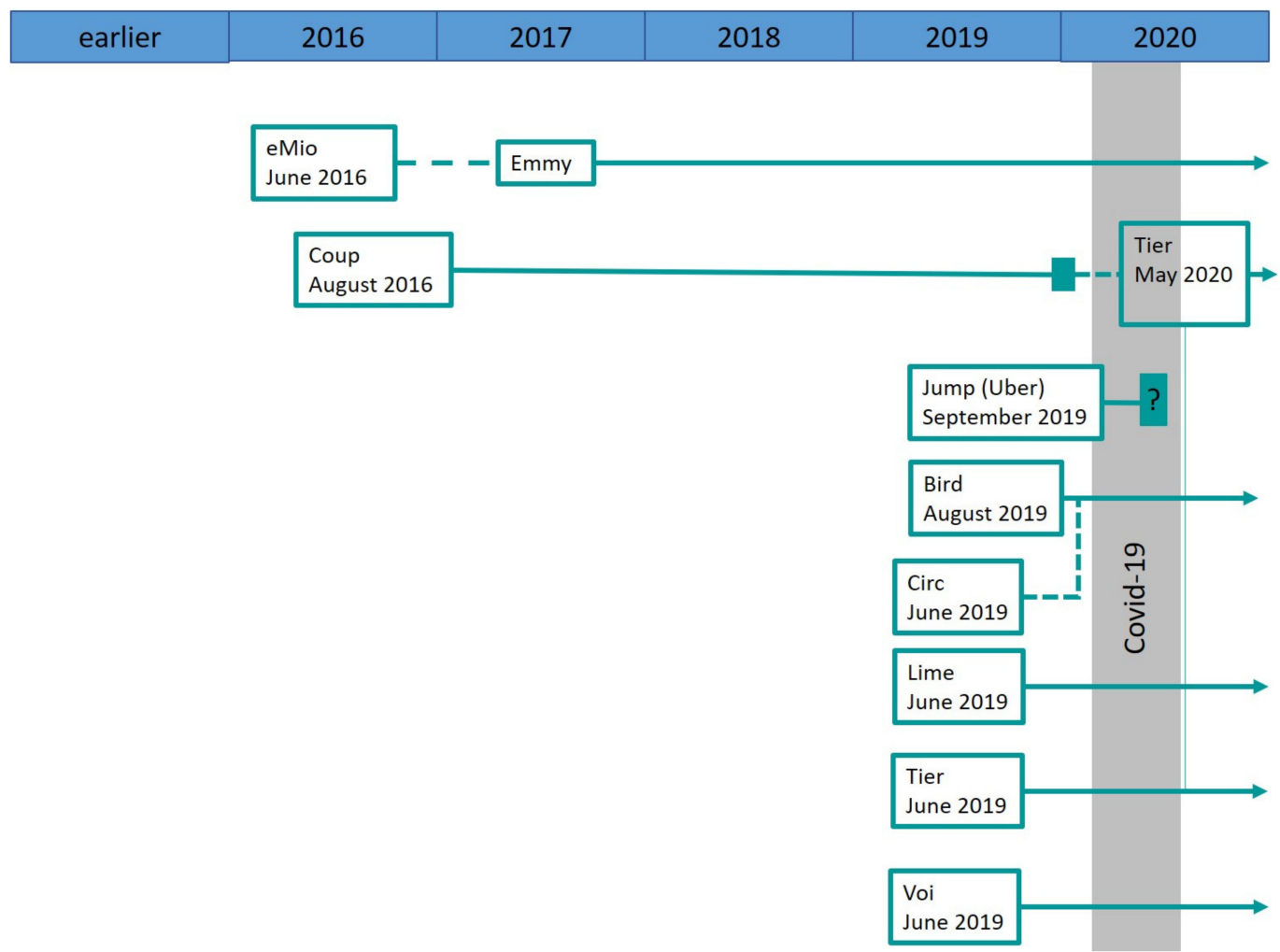

Figure 2. Market entry and exit of moped- and e-scooter-sharing providers in Berlin. Source: Own research.

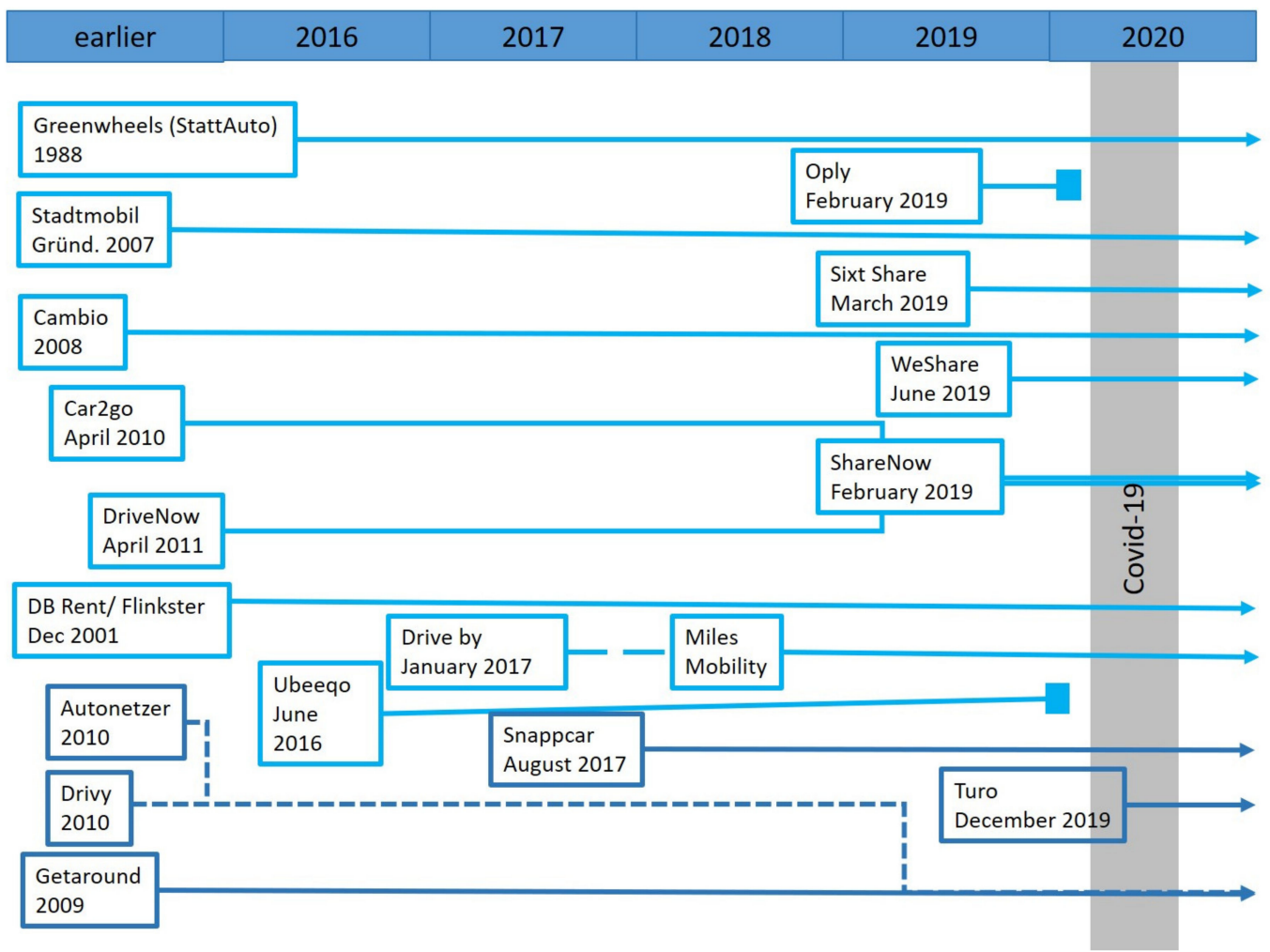

Figure 3. Market entry and exit of car-sharing providers in Berlin. 


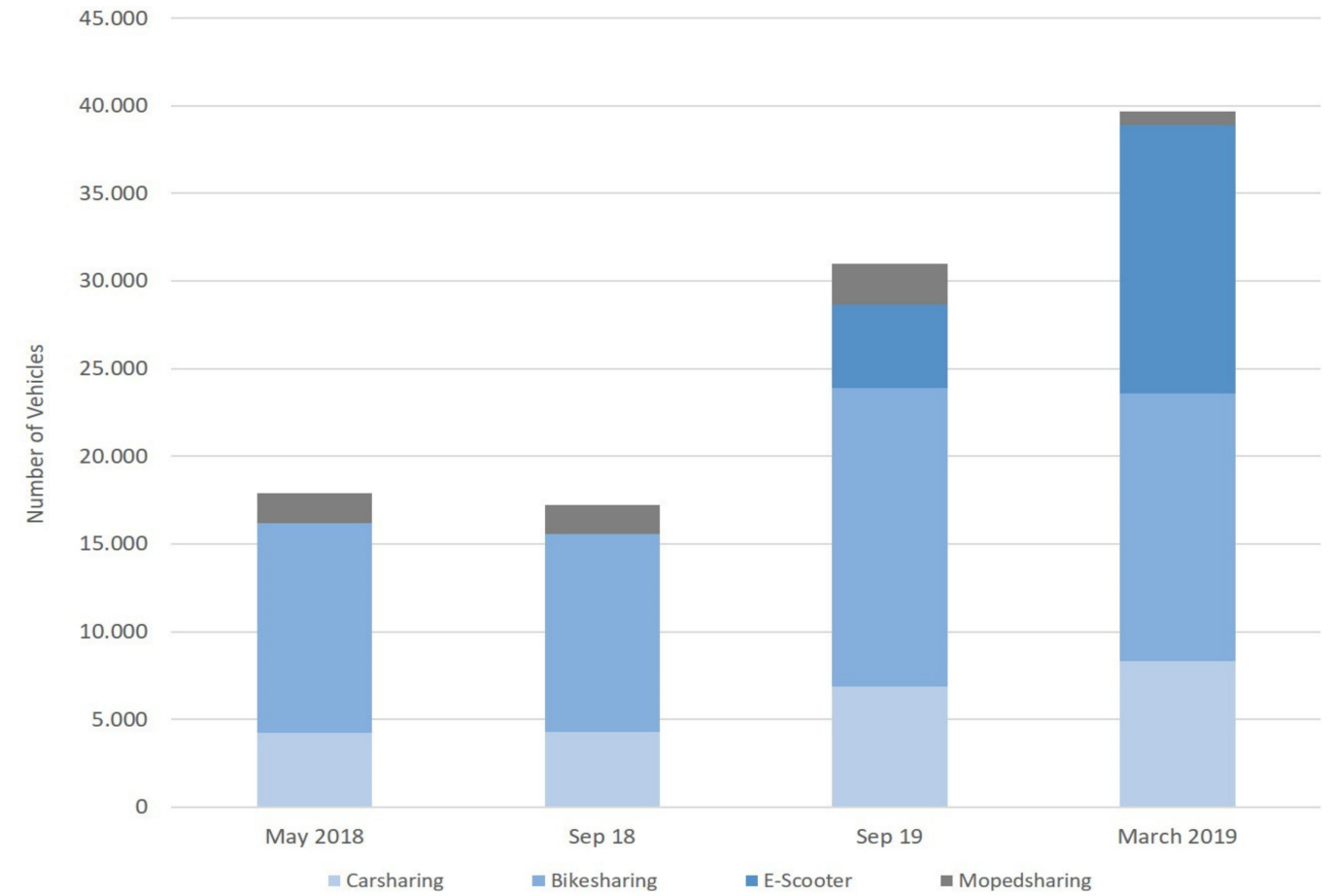

Figure 4. Fleet size of shared mobility providers in Berlin, 2018-2019. Adapted from [10]; estimations based on desk research.

\subsection{Limited Action Spaces for Regulation}

The relatively sudden upscaling of these different types of mobility services triggered a public debate in the local media but also in the political realm (for e-scooters [69]). Some key questions were whether cities should accept, support, or discourage the growth of these services. Would SMS lead to fewer cars on the roads or merely help to raise profits for global players of the digital industries? Might it not be better if a transition to sustainable mobility were driven exclusively by cycling, walking, and public transit? Or could a lack of support lead to the collapse of the new diversity of mobility services in the city? These questions were debated in the local media as well as in the political realm. At the same time, the growth of SMS also triggered legal questions. As recent studies have shown, the regulatory context in Germany is different than that of many other countries where cities have started to regulate free floating mobility services [12]. There is still substantial disagreement on the questions of if and how cities in Germany are allowed to regulate SMS. At the center of the legal debate is the differentiation of "common use" ("Gemeingebrauch") and "special use" ("Sondernutzung") in the German legal framework [3,60]. Koschmieder and Huß [70] argue that placing rental vehicles in the public realm is legally part of the "common use" of streets. According to this interpretation, the parking of rental vehicles, just as the parking of private vehicles, should not be seen as a "special use" ("Sondernutzung"). Cities thus would currently have no legal basis for requiring services to apply for a license, set limits to the number of vehicles or the number of providers, or set requirements for other elements of service design.

Some cities such as Düsseldorf and Leipzig have recently adopted a different position, declaring e-scooter services a form of "special use" that requires a license and comes with a set of fees and rules [71,72]. In Berlin, the state government is currently deliberating if similar regulation would be legally feasible. A recent legal analysis came to the conclusion that the legal framework currently does not allow for a final determination of this question [73]. Some authors have since suggested changing the legal framework to allow cities to regulate free floating services $[60,69]$. On the national level, changes of transport regulation were suggested, exempting the deployment of free floating 
rental vehicles on sidewalks from the concept of "common use" and requiring providers to seek a permit. Yet this attempt failed to pass [73]. Against the background of uncertain legal conditions for regulation, Berlin has not yet introduced formal regulation on SMS. A third part of the mobility act, which is currently being drafted, will set down principles for dealing with SMS and other new forms of "intelligent mobility" in the city.

Given the difficulty of introducing actual regulation in reaction to the upscaling of SMS, the years 2018 and 2019 were instead marked by formal and informal communication between public authorities and service providers about the arising problems and possible solutions. One informal forum was a workshop series, the results of which are presented in Section 4.

\section{Exploring Potential for Conflict or Coalition Building: Insights from a Workshop Series}

\subsection{Format, Aims, and Goals of the Workshop Series}

The relatively sudden proliferation of SMS in the city provided an opportunity to study the different perspectives of SMS providers and representatives of public authorities. To this aim, the author, together with fellow researchers, invited service providers to a workshop series. The aim was to bring providers of different services together with representatives of public authorities to informally discuss the role of their services in a local transport transition. The workshop invitation was send to all providers of shared mobility services (car-sharing, bike-sharing, e-scooter-sharing, moped-sharing) who were active in Berlin at the given time. Between March 2018 and January 2020, ten workshops were held. The number of participants varied. Most workshops were attended by 8-16 representatives of service providers (the lowest number of participants was four). Beginning with the first workshop, we also invited employees from the Department of Transport of Berlin as well as from two boroughs who were interested in cooperating with SMS providers. Some participants from public authorities stressed that the opinions that they expressed in the workshops were not necessarily in congruence with official positions of their employer. This was in keeping with the concept of the workshops, which were designed as a forum for informal discourse. The workshops were documented in the form of hand-written notes. In order to encourage participants to speak freely, the workshop proceedings were not recorded and no formal protocol was made. After each workshop, the team used the notes to discuss the results against the backdrop of the main research questions and to identify the key findings. The following account comprises an extract of the results.

The main research question behind the workshops was twofold: First, we wanted to explore which problems SMS providers encountered in introducing their services in the city. While the public debate at the time focused strongly on the possible negative impacts of SMS, we wanted to explore the perspective of SMS providers on these issues. We also wanted to explore the potential for collaboration between different service providers: Did they perceive themselves as part of a group that shared common challenges and interests vis-à-vis public authorities? Secondly, we wanted to bring in the perspective of public authorities to explore their perception of SMS. The main question was if the two groups could agree on solutions for some of the problems identified. Was there potential for coalition-building between cities and SMS providers to reduce the dominance of the private car? The workshops thus centered around three main questions:

1. Which problems did SMS providers perceive in the interaction with public authorities? Seen from their perspective, how could city authorities support the growth of SMS?

2. Did SMS providers from different market segments see similar challenges? Could they agree on common interests?

3. Which problems and concerns did representatives of the municipal/state level have regarding the rise of SMS? To what extent could providers and municipal actors agree on possible solutions for the problems identified?

In the first session, we asked SMS providers to describe the main challenges that they confronted in rolling out their services in the city. Beginning with the second session, we also asked municipal 
representatives to describe the main "pain points" that they saw vis-à-vis SMS. The following workshop sessions revolved around further exploring these key points and discussing different possible solutions that would benefit the city while also allowing providers keep providing their services in the city.

\subsection{Key Findings: Problem Perceptions of SMS Providers and Public Authorities}

The main topics that came up in the workshop discussion revolved around four key dimensions: "access to public space", "spatial coverage", "access to data", and "communication".

\subsubsection{Access to Public Space}

As was expected, one of the most intensely debated issues related to the use of public space. Some municipal actors said that while they generally saw the potential of SMS for sustainable mobility, they were concerned that bikes and e-scooters were "cluttering" public space and "flooding" the streets with their vehicles. A major concern was to keep sidewalks accessible for pedestrians, especially citizens with disabilities. Some also voiced concern that FFCS services were bringing even more cars into the city, thus undermining the goal of reducing the number of cars overall. Some municipal actors also doubted the spatial efficiency of FFBS and FFSC: Were they really being used more often than private vehicles? Some stated that cities should be able to charge fees for deployment of bike-sharing and other small vehicles in the public realm, even if this would necessitate changes to the legal framework.

Most service providers, on the other hand, stressed that their service was an important contribution to mobility in the city, and therefore their use of public space was justified. Some also stressed that they offered an alternative to private cars, which were using much more space within the city. They also compared the size of their fleets to the overall number of private cars in Berlin (around 40,000 shared mobility vehicles in comparison to 1.2 million private cars). They also stressed that under current regulations, the deployment of free-floating vehicles was allowed as part of the "common" use of public road space. Most FFBS/FFES providers expressed that fees would endanger their business model and might lead to a significant reduction in SMS in the city. Most providers also stated that fees would put SMS vehicles into a disadvantage in comparison to privately owned vehicles.

In relation to access to public space, some important differences between the different market segments came to light. Station-based car-sharing providers stressed the importance of reliable access to reserved parking spaces for their business model. For them, being able to rent fixed parking spaces in the city would be most important in order to scale up their services. FFCS providers stressed that their business model functioned without designated parking spots. Nonetheless, they conceded that reserving parking spaces for FFCS could be a way of making car-sharing use much more attractive in comparison to the private car. If cities wanted to foster the use of FFCS, they should offer discounted parking rates for these vehicles. Providers of FFBS/FFES services stressed that flexible use of space was very important to them. In their view, their users highly appreciated the fact that they could pick up and drop off vehicles on every corner without having to go to a designated parking area. At the same time, many agreed that having designated parking areas could also be beneficial for shared bikes and scooters, but they also stressed that they did not want to be forced to revert to station-based models.

A number of possible solutions for the problems concerning access to public space emerged from the discussions. Many providers of FFBS/FFES expressed their willingness to keep places of special interest in the city more "uncluttered", e.g., by using geo-fencing methods. Another possible solution for "decluttering" public space was the idea that municipal actors could create parking spaces for SMS, either in the form of smaller designated parking areas for car-, bike-, and scooter-sharing or as larger mobility hubs, e.g., at PT stations. In this point, a potential match was identified between the goals of municipal actors to reduce private car travel and the goals of service providers; creating designated parking areas for all types of services by replacing car parking spaces was seen by some as a potential "win-win" solution. Dedicated parking areas for FFBS and FFES would not be placed on already cluttered sidewalks, but on the street, by repurposing car parking spaces. This approach was later adopted by the borough of Friedrichshain-Kreuzberg. In 2019, the borough set itself the 
goal to repurpose up to 500 car parking spaces as designated parking areas for e-scooters and other small electric vehicles in the coming years [74]. In 2020, 20 car parking spaces were repurposed [75]. Other boroughs are still deliberating if they will follow the example. Another step in this direction was taken by the public transport provider BVG in 2019 by starting to create "mobility hubs" at several PT stations, even though these were built on private ground instead of replacing car parking spaces [76].

\subsubsection{Coverage: City Center Versus Outskirts}

The second key theme also revolved around space, namely the issue of spatial coverage of the services. Some municipal actors stated their expectation that SMS should primarily "complement" public transport; they should mainly be provided where PT quality was not optimal, namely in the outer districts of Berlin. They also stressed the importance of reliable service. Instead of the flexible free floating models, they favored the idea that users should reliably find a bike, car, or scooter in the vicinity of PT stations, especially in suburban areas.

Many service providers, on the other hand, stated that they could not easily expand their service to places of low demand. Some differences between market segments emerged regarding this question. Some station-based service providers stressed that they were already present in a number of places beyond the city core and were constantly experimenting with new locations, often in cooperation with housing companies. Some providers of FFBS/FFES also stressed that they were constantly experimenting with expanding their business areas. They described that technical barriers to such experiments were quite low, thanks to the digital nature of their service. Yet, so far, most experiments in outer districts had not proven to be financially viable.

A number of possible solutions for this issue were discussed in the workshops. Some municipal actors stated that municipalities should be allowed to create licensing schemes, thereby limiting the number of service providers while also making it mandatory to serve inner and outer parts of the city. This would necessitate changes in the legal framework. Reactions from service providers were mixed, with some stating that licensing schemes could work for them, depending on the concrete conditions. They also stressed that under the current legal framework, cities could not make a license mandatory for free-floating services. FFCS providers related their experiences with voluntary agreements with different municipalities, where lower parking fees in the city center were combined with an obligation to extend the service area beyond the city core. It was discussed if such a voluntary solution could be found in Berlin, but no concrete offer was made from the side of public authorities to that avail.

\subsubsection{Access to Data}

A third controversial topic concerned the access to booking data. Some municipal actors demanded access to data, specifically regarding the spatial distribution of vehicles, the frequency of use, and the spatial distribution of demand. They stressed that cities needed to have access to data to improve transport planning but also to retain some control over services operating in the city. It became clear in some of the statements that administration officials felt that public interests might be threatened by the sudden appearance of large vehicle fleets. Most service providers argued that they were not legally bound to provide booking data to authorities but stated that they were generally willing to share certain data with municipalities and in some cases were already doing so. However, most were reluctant to "give away" data without specific benefits. Some said they did not feel confident that municipal actors would actually use the data in a productive way. It also became clear that some providers were reluctant to share data with their competitors.

A possible solution was discussed in which all service providers in the city would agree to integrate into a common app together with public transport. This would increase public utility by giving users access to different services without having to subscribe to several apps, while also giving access to booking data to the publicly owned public transport company. Most SMS providers did not want to be "forced" to integrate their service on a common app. They stressed that a growing number of private sector apps was currently being developed that integrated several services. Yet, a number of 
service providers expressed a general openness to integration on a voluntary basis. This solution was later partially realized in the form of the app Jelbi, which integrates several providers of car-, bike-, and scooter-sharing on the platform of the public transport provider BVG (though FFCS services are missing). It is now used by around 110,000 users [76].

\subsubsection{Communication}

Problems relating to communication were a prominent topic in the workshop discussions. One set of problems related to communication between service providers and public authorities. Many service providers reported problems in communicating with municipal actors. Most stressed their willingness to cooperate with the municipality in the roll-out of their services, but some reported problems with finding officials in the administration responsible for their case. There were also substantial differences between different service types: Most car-sharing providers had a long history of cooperation with city authorities, while providers of FFBS and FFES had no previous experience in the German context. Some representatives of public authorities voiced their general willingness to engage in regular communication with SMS providers but found it difficult to deal with the sudden appearance of so many different new market players. One possible solution that was discussed was the creation of a new position of "Shared Mobility Manager" in the administration. This job would entail coordinating the administrative response to and communication with all types of SMS providers. Two problems were lack of personnel and the fact that many key issues (e.g., the provision of designated parking areas) lay beyond the jurisdiction of the state of Berlin and lay instead with the local boroughs (Bezirke).

Another dimension of communication related to potential cooperation between service providers of different segments. In the first session, an interesting finding was that most representatives of different market segments (car, bike, etc.) had never before met each other. It also emerged that this was the first time that, for example, car-sharing representatives had engaged intensively with bike-sharing providers. Car-sharing providers proved to be the most established and experienced players in the German context. In this sector, competitors had a history of cooperation. In 2017 a new legal framework was created that allowed municipalities to designate parking spots for car-sharing vehicles [60]. It was the result of many years of lobbying efforts in which many car-sharing providers cooperated.

Most representatives of the other sectors, with the exception of station-based bike-sharing, were clearly less experienced in dialoguing with each other and with city authorities. In this context it was discussed whether or not service providers from the different segments could establish a formal association representing their common interests. In spite of different opinions and interests in specific questions, all providers agreed that shared mobility vehicles should not be disadvantaged by legislation or regulation in comparison to non-shared vehicles. Yet, over the course of the workshops, it became clear that there was not (yet) enough common ground for competitors to take this step.

The key findings are summed up in Table A1 in Appendix A.

\section{Discussion: Windows of Opportunity for a Re-Distribution of Public Space?}

\subsection{Upscaling and Breakthrough in the Context of Established Regime Structures}

The findings from the workshops can now be interpreted in the light of the theoretical framework developed above. The proliferation of SMS in Berlin between 2018 and 2020 can be seen as an example of sudden upscaling dynamics of former niche innovations. In this phase, innovations become so large scale that they start to challenge the existing regime structures by their sheer presence. As the example of Berlin showed, the upscaling of SMS suddenly made former niche innovations such as car-, bike-, and scooter-sharing highly visible in public space. New practices of mobility increasingly became a visible part of everyday life. The concept of a "multioptional mobility system" appeared to transform from a vision to a reality. At the same time, the potential conflicts of interest and negative externalities arising in such a new mobility system also became visible and became the subject of open political debate. 
One of these is that a shift to multioptional mobility can increase the power of market actors who are not driven by ecological motivations. In the car-sharing sector, many providers are subsidiaries of large and powerful companies. Most providers of FFBS and FFES are international companies backed by substantial financial power. A transition to a multioptional mobility system potentially increases the power of these new (and also old) market actors who offer the services at scale and for profit. From an analytical perspective on transformation, the upscaling of SMS thus needs to be seen as an expression of capitalist market dynamics of digitization. They put pressure on the existing regime structures, forcing established actors such as the automobile industry to adapt while also generating opportunities for new players to enter the mobility market. In this sense, the growth of SMS highlights that a transformation to a multioptional mobility system will not necessarily lead to a more sustainable mobility system. Instead, public authorities will increasingly be confronted with the question of how to regulate SMS in accordance with sustainability goals. In Berlin, these questions of governance suddenly became acute.

\subsection{Conflict or Coalition Building?}

The issue of public space in Berlin had already become re-politicized in the context of the mobility act; the upscaling of SMS further contributed to this political "street fight". From the perspective of public authorities, a completely new set of commercial actors claimed access to public space to implement their business models. This triggered political debate, especially around the legitimate use of public space, challenging political authorities to act. In this context, the workshop results revealed several points of conflict, but also potential avenues for coalition-building between public authorities and SMS providers. Specifically, the workshops showed that the business model of SMS providers strongly depends on the regulatory context. From their perspective, one of the biggest challenges is finding space for their vehicle fleets in the public realm. In their role as "contenders", SMS providers revealed a strong interest in regulatory changes in their favor (e.g., the reduction of parking fees for FFCS vehicles) and a strong interest in stopping regulatory changes that were not in their favor. Specifically, providers of FFBS and FFES wanted to avoid the introduction of new fees for their vehicles in public space. This is why the attitudes of public authorities towards SMS were of substantial importance to SMS providers. Public authorities in Berlin, on the other hand, had a strong interest in regulating SMS, but the legal framework severely limited their action space. At the same time, most of the representatives of public authorities in Berlin who attended the workshops shared a strong interest in fostering a reduction of car use. From this perspective, they generally supported the idea of SMS but were unsure whether or not to encourage the upscaling of these commercial services. Most wanted SMS to play a complementary role to public transport and feared the services could become competition for PT, especially in the city center.

In this context, a potential trade-off emerged. Some municipal actors who took part in the workshops were open to the possibility of using the upscaling of SMS as an opportunity to reduce the number of car parking spaces by turning them into designated spaces for car-, bike-, or scooter-sharing. In exchange, some wanted the SMS providers to extend their services beyond the city core and comply with a set of rules regarding "decluttering" public spaces and providing data for transport planning. As already mentioned above, one borough of Berlin actually started to turn car parking spots into designated parking spots for e-scooters.

\subsection{Complexity Unfolding: Upscaling and Feedback Loops}

From the perspective of system dynamics, this trade-off can be seen as an example of a potential positive feedback loop. Using the growth of SMS as an opportunity to re-distribute public space away from private cars could help to make alternatives to private car use more attractive. Growing demand for these alternatives can, in turn, fuel an agenda of further reduction of car space. This perspective adds a new dimension to the evaluation of SMS and their role in sustainability transitions. Following Urry [25] systemic change can become possible when many different trends and developments converge, 
which pressure the normal workings of system structures. Berlin in 2018 and 2019 saw such a convergence of different factors. The upscaling dynamic of SMS coincided with the rising levels of cycling, the political efforts of grass roots initiatives demanding more space for cycling, and a local government that was aiming to reduce car traffic. It intensified the ongoing political "street fight" [21] in the city. Who should have access to public space? Should rental vehicles be treated differently than private vehicles and specifically private cars? SMS challenged the long-established dominance of privately owned vehicles in the public realm. They brought up the question of whether parking spaces should better be reserved for private vehicles or for commercial vehicles that can potentially be used by more than one household. These questions added to the ongoing debate around the redistribution of space in favor of cycling, walking, and PT. Together, these factors re-politicized the use of public space, potentially creating windows of opportunity for more radical change.

\section{Conclusions}

In this article, I explored the role of SMS such as car-, bike-, and e-scooter-sharing in a transition to a less car-centered mobility system. While many studies have looked into user groups, usage patterns, and immediate effects of SMS on urban transport systems, my exploration focused on the potential role of SMS in the context of complex system dynamics of transition processes. Using the theoretical framework of the MLP combined with elements of the sociology of technology I analyzed the market growth of SMS in Berlin in 2018 and 2019 as an example of upscaling dynamics of (former) niche innovations. Building on a workshop series with SMS providers and representatives of public authorities in Berlin, I showed how the upscaling of SMS created potential for conflict as well as coalition-building between service providers and public authorities. The example of Berlin illustrates how new and powerful actors start to claim access to public space for their business models. It also illustrates how this could be used by public authorities as a window of opportunity to further their agenda of redistributing public space away from private car traffic. City authorities could increasingly replace parking spaces for private cars by designated parking areas for SMS. At the same time, they could use this as an incentive for agreements with SMS providers to expand their services to cover different areas of the city. Potentially, such a trade-off might trigger a positive feedback loop, making alternatives to private car travel more attractive while also "pushing" out private car traffic.

While such trade-offs may be feasible on the basis of voluntary agreements, a transition to sustainable mobility will also need changes of the regulatory framework. As many authors have pointed out, cities will need to be empowered to pass binding regulation for different types of transport services [60]. With powerful actors entering the field of SMS, the contours of a new socio-technical regime of multioptional mobility become visible. If this development is to be steered in the direction of sustainability, cities will need a legal framework that allows them to regulate all types of mobility services, but also private vehicles, in a more integrated manner [77]. More stringent regulation should avoid putting rental vehicles at a disadvantage in comparison to private vehicles. Charging fees for e-scooters may prove counterproductive as long as private cars continue to park for free in most areas. This is why regulatory changes first and foremost need to enable cities to enact tougher regulations on car traffic [64]. At the moment, cities in Germany are not allowed to introduce congestion charges or to introduce general speed limits of $30 \mathrm{~km} / \mathrm{h}$ on central roads [60]. These types of regulations would have the strongest effects on reducing private car traffic.

The MLP has proven useful for studying the dynamics of acceleration and upscaling of (former) niche innovations such as car-, bike-, and e-scooter-sharing in the context of sustainability transitions in the transport sector. In accordance with the analysis by Köhler et al. [24], it can be said that the transport sector has recently been marked by the upscaling of former niche innovations. A breakthrough of shared mobility use in the context of a growing socio-technical system of "multioptional mobility" is increasingly becoming a realistic possibility-at least in large cities. This also means that shared mobility may increasingly become a mass market and an important business model. From the point of view of sustainability transitions, this means that new governance models need to be found to steer this 
development in the direction of ecological sustainability. Without regulatory support, SMS may remain a niche innovation that adds to, rather than reduces, the number of vehicles on the road. FFBS/FFES would continue to share the space with regular cycling and walking, while the space for car parking would remain largely the same as today. By contrast, in a strong policy scenario, municipal actors and regulators on the national level could use the window of opportunity to redefine the rules for access to public space. In this case, a feedback loop could create a growing demand for cycling, walking, and SMS while also making private car ownership less attractive.

Further research should look more closely into the governance challenges posed by growing fleets of SMS, especially when it comes to spatial coverage. A key question is how cities can ensure that growing fleets of SMS are not concentrated exclusively in the city center but spread to suburban areas [12]. Another key question is how cities can be empowered to deal with new and powerful actors whose business model depends on the use of public space as well as on exclusive access to data [12]. Further research should also include a stronger focus on the role of users of SMS in a transition. A promising research question is to what extent SMS user groups accept or even demand a re-distribution of space away from cars in favor of SMS [5]. From the perspective of the normative concept of socio-ecological transition, it is also clear that ecological mobility will have to go beyond a modal shift. It also needs to come with a reduction in overall travel demand. Visions of a "good life for all" [39] will need to encompass a life with fewer distances traveled. While the article focused on the goal of a modal shift, future research also needs to explore the role of upscaling dynamics and feedback loops for the implementation of sufficiency-oriented transport policy measures.

Funding: This research was funded by a grant from the Mercator Foundation as well as a grant from the German Federal Ministry of Science and Education (BMBF). "The publication of this article was funded by the Open Access Fund of the Leibniz Association."

Conflicts of Interest: The author declares no conflict of interests.

\section{Appendix A}

Table A1. Key findings: Problem perceptions of SMS providers and public authorities.

\begin{tabular}{|c|c|c|c|c|}
\hline & $\begin{array}{c}\text { Perspective of Service } \\
\text { Providers }\end{array}$ & $\begin{array}{c}\text { Key Characteristics of } \\
\text { Specific Market Segments } \\
\text { (Car-, Bike, E-Scooter-, } \\
\text { Mopedsharing) }\end{array}$ & $\begin{array}{c}\text { Perspective of } \\
\text { Municipal Actors }\end{array}$ & $\begin{array}{c}\text { Possible Solutions } \\
\text { Discussed in the Workshops }\end{array}$ \\
\hline $\begin{array}{c}\text { Access to } \\
\text { public space }\end{array}$ & $\begin{array}{l}\text { Need access to public } \\
\text { space especially in } \\
\text { central } \\
\text { places/(tourist) hotspots; } \\
\text { Want to avoid fees to } \\
\text { keep down costs for } \\
\text { users/protect volatile } \\
\text { business model }\end{array}$ & $\begin{array}{l}\text { Station-based services: } \\
\text { reliable access to } \\
\text { reserved } \\
\text { parking spaces } \\
\text { Free-floating services } \\
\text { appreciate designated } \\
\text { parking areas but fear } \\
\text { to be forced to offer } \\
\text { station-based models }\end{array}$ & $\begin{array}{l}\text { - Fear "cluttering" of } \\
\text { public space; } \\
\text { Want to keep } \\
\text { sidewalks accessible } \\
\text { for pedestrians, } \\
\text { especially } \\
\text { with disabilities; } \\
\text { - Fear "flooding" of the } \\
\text { city by large scale } \\
\text { fleet operators; want } \\
\text { fewer cars in the city. }\end{array}$ & $\begin{array}{l}\text { - Creating designated } \\
\text { parking areas } \\
\text { ("Mobilpunkte") in } \\
\text { residential streets but } \\
\text { also in locations of } \\
\text { special interest (e.g., } \\
\text { tourism hot spots) } \\
\text { Creating mobility hubs at } \\
\text { central locations close } \\
\text { to PT } \\
\text { (“Mobilitätsstationen") } \\
\text { Possible "win-win" by } \\
\text { replacing car } \\
\text { parking spaces }\end{array}$ \\
\hline Coverage & $\begin{array}{l}\text { Want to introduce } \\
\text { services where } \\
\text { revenues are high } \\
\text { Do not want to provide } \\
\text { services where demand } \\
\text { is deemed to be low }\end{array}$ & $\begin{array}{l}\text { Free-floating services } \\
\text { find it easier to } \\
\text { experiment with new } \\
\text { service areas than } \\
\text { station-based services }\end{array}$ & $\begin{array}{l}\text { - Want SMS to be } \\
\text { available beyond the } \\
\text { city core, especially in } \\
\text { outer districts where } \\
\text { it "complements" PT } \\
\text { Want reliable service, } \\
\text { especially at } \\
\text { PT stations }\end{array}$ & $\begin{array}{l}\text { - Creating licensing } \\
\text { schemes with mandatory } \\
\text { spatial coverage } \\
\text { requirements (e.g., by } \\
\text { combining service in } \\
\text { areas of high and low } \\
\text { demand) (legal } \\
\text { uncertainty as a hurdle) } \\
\text { Voluntary agreements, } \\
\text { e.g., granting reduced } \\
\text { parking fees in return for } \\
\text { broader coverage }\end{array}$ \\
\hline
\end{tabular}


Table A1. Cont.

\begin{tabular}{|c|c|c|c|c|}
\hline & $\begin{array}{c}\text { Perspective of Service } \\
\text { Providers }\end{array}$ & $\begin{array}{c}\text { Key Characteristics of } \\
\text { Specific Market Segments } \\
\text { (Car-, Bike, E-Scooter-, } \\
\text { Mopedsharing) }\end{array}$ & $\begin{array}{c}\text { Perspective of } \\
\text { Municipal Actors }\end{array}$ & $\begin{array}{l}\text { Possible Solutions } \\
\text { Discussed in the Workshops }\end{array}$ \\
\hline Data & $\begin{array}{l}\text { - Want to avoid "giving } \\
\text { away" data (threat to } \\
\text { data based } \\
\text { business models) } \\
\text { Hesitate to share data } \\
\text { with competitors }\end{array}$ & & $\begin{array}{l}\text { Want data for } \\
\text { transport planning; } \\
\text { Want to safeguard } \\
\text { public interests } \\
\text { - Want to retain control } \\
\text { over "what is going } \\
\text { on" in the city }\end{array}$ & $\begin{array}{l}\text { Integrating services on a } \\
\text { common app (either by } \\
\text { creating a legal } \\
\text { requirement or by } \\
\text { voluntary agreement) }\end{array}$ \\
\hline Communication & $\begin{array}{l}\text { Want to improve } \\
\text { communication with } \\
\text { municipal actors; } \\
\text { Want to improve their } \\
\text { image in the } \\
\text { public/the media } \\
\text { Are gauging the } \\
\text { potential for } \\
\text { cooperation with each } \\
\text { other to foster their } \\
\text { common interests }\end{array}$ & $\begin{array}{l}\text { Carsharing providers } \\
\text { more experienced in } \\
\text { communicating with } \\
\text { authorities in Germany }\end{array}$ & 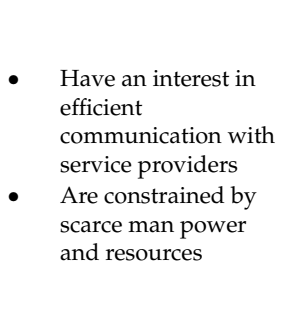 & $\begin{array}{l}\text { - Creating a new position } \\
\text { of "Shared Mobility } \\
\text { Officer" in } \\
\text { the administration } \\
\text { Forming an } \\
\text { institutionalized special } \\
\text { interest group to } \\
\text { strengthen influence on } \\
\text { political process }\end{array}$ \\
\hline
\end{tabular}

\section{References}

1. Masson-Delmotte, V.; Zhai, P.; Pörtner, H.-O.; Roberts, D.; Skea, J.; Shukla, P.R.; Pirani, A.; Moufouma-Okia, W.; Péan, C.; Pidcock, R.; et al. (Eds.) IPCC2018: Summary for Policymakers. In Global Warming of $1.5^{\circ} \mathrm{C}$. An IPCC Special Report on the Impacts of Global Warming of $1.5^{\circ} \mathrm{C}$ Above Pre-Industrial Levels and Related Global Greenhouse Gas Emission Pathways, in the Context of Strengthening the Global Response to the Threat of Climate Change, Sustainable Development, and Efforts to Eradicate Poverty; IPCC: Geneva, Switzerland, 2018; in press. Available online: https://www.ipcc.ch/site/assets/uploads/sites/2/2019/05/SR15_SPM_version_report_LR.pdf (accessed on 1 September 2020).

2. BMU 2020: Klimaschutz in Zahlen: Sektorenziele 2030. Available online: https://www.bmu.de/fileadmin /Daten_BMU/Download_PDF/Klimaschutz/klimaschutz_in_zahlen_sektorenziele2030_bf.pdf (accessed on 1 September 2020).

3. Agora Verkehrswende. Klimaschutz im Verkehr: Maßnahmen zur Erreichung des Sektorziels 2030; Agora Verkehrswende: Berlin, Germany, 2018.

4. Winkler, C.; Seum, S. Mobilitätsszenarien 2040: Verkehrswachstum und Treibhausgasminderungen-Geht das zusammen? Ph.D. Thesis, Verkehrswissenschaftliche Tage, Dresden, Germany, 14-15 March 2018.

5. Ruhrort, L. Transformation im Verkehr. In Erfolgsbedingungen für Verkehrspolitische Schlüsselmaßnahmen; Springer: Wiesbaden, Germany, 2019.

6. Geels, F.W. A socio-technical analysis of low-carbon transitions: Introducing the multi-level perspective into transport studies. J. Transp. Geogr. 2012, 24, 471-482. [CrossRef]

7. Gerike, R.; Hubrich, S.; Ließke, F.; Wittig, S.; Wittwer, R. Was sich zeigt. Präsentation und Diskussion der Ergebnisse des SrV 2018, Ergebnisdarstellung zum 11. In Erhebungsjahrgang, Mobilität in Städten-SrV 2018; Technische Universität Dresden: Dresden, Germany, 13 March 2020.

8. Andor, M.; Frondel, M.; Horvath, M.; Larysch, T.; Ruhrort, L. Präferenzen und Einstellungen zu vieldiskutierten verkehrspolitischen Maßnahmen: Ergebnisse einer Erhebung aus dem Jahr 2018. List Forum Für Wirtsch. Und Finanzpolit. 2020, 45, 255-280. [CrossRef]

9. Schwedes, O. Das Berliner Mobilitätsgesetz. Ein entscheidender Beitrag zur "Verkehrswende" in der Hauptstadt!-Eine Entgegnung. Planerin 2018, 6, 52.

10. Scherf, C.; Knie, A.; Pfaff, T.; Ruhrort, L.; Schade, W.; Streif, M. Mobilitätsmonitor Nr. 10. Stadt- und Straßenbahn, Shared Mobility, Taxi und Funkmietwagen, Einzugsraum des ÖPNV. Int. Verk. 2020, 72, 40-43.

11. Docherty, I.; Marsden, G.; Anable, J. The governance of smart mobility. Transp. Res. Part A Policy Pract 2018, 115, 114-125. [CrossRef] 
12. Polis 2019: Macro Managing Micro Mobility. Taking the Long View on Short Trips. Discussion Paper. Available online: https://www.polisnetwork.eu/wp-content/uploads/2019/11/Polis-Paper-Macromanaging -MicroMobility.pdf (accessed on 1 September 2020).

13. Canzler, W.; Knie, A.; Ruhrort, L.; Scherf, C. Erloschene Liebe? In Das Auto in der Verkehrswende; Transcript: Bielefeld, Germany, 2018.

14. Kuhnimhof, T.; Nobis, C.; Hillmann, K.; Follmer, R.; Eggs, J. Veränderungen im Mobilitätsverhalten zur Förderung Einer Nachhaltigen Mobilität-Schlussbericht; Umweltbundesamt: Dessau-Roßlau, Germany, 2019. Available online: https://elib.dlr.de/133798/1/2019-08-29-texte_101-2019_mobilitaetsverhalten.pdf (accessed on 1 September 2020).

15. Mont, O.K. Clarifying the concept of product-service system. J. Clean. Prod. 2002, 10, 237-245. [CrossRef]

16. Schaefers, T. Exploring Carsharing Usage Motives: A Hierarchical Means-end Chain Analysis. Transp. Res. Part A Policy Pract. 2013, 47, 69-77. [CrossRef]

17. Plewnia, F.; Guenther, E. Mapping the sharing economy for sustainability research. Manag. Decis. 2018, 56, 570-583. [CrossRef]

18. Becker, H.; Balac, M.; Ciari, F.; Axhausen, K.W. Assessing the welfare impacts of Shared Mobility and Mobility as a Service (MaaS). Transp. Res. Part A Policy Pract. 2020, 131, 228-243. [CrossRef]

19. Pangbourne, K.; Mladenović, M.N.; Stead, D.; Milakis, D. Questioning mobility as a service: Unanticipated implications for society and governance. Transp. Res. Part A Policy Pract. 2020, 131, 35-49. [CrossRef]

20. Buhler, R. Transport Policies, Automobile Use, and Sustainable Transport: A Comparison of Germany and the United States. J. Plan. Educ. Res. 2010, 30, 76-93. [CrossRef]

21. Henderson, J.; Gulsrud, N.M. Street Fights in Copenhagen: Bicycle and Car Politics in a Green Mobility City; Routledge: London, UK, 2019.

22. Geels, F.W.; Schwanen, T.; Sorrell, S.; Jenkins, K.; Sovacool, B. Reducing energy demand through low carbon innvovation: A sociotechnical transitions perspective and thirteen research debates. Energy Res. Soc. Sci. 2018, 40, 23-35. [CrossRef]

23. Geels, F.; Kemp, R.; Dudley, G.; Lyons, G. Automobility in Transition? A Socio-Technical Analysis of Sustainable Transport; Routledge: London, UK, 2011.

24. Köhler, J.; Geels, F.W.; Kern, F.; Markard, J.; Wieczorek, A.; Alkemade, F.; Avelino, F.; Bergek, A.; Boons, F.; Fünfschilling, L.; et al. An agenda for sustainability transitions research: State of the art and future directions. Environ. Innov. Soc. Transit. 2019, 31, 1-32. [CrossRef]

25. Urry, J. The System' of Automobility. TheoryCult. Soc. 2004, 21, 25-39. [CrossRef]

26. Watson, M. How theories of practice can inform transition to a decarbonized transport system. J. Transp. Geogr. 2012, 24, 488-496. [CrossRef]

27. Smith, A.; Raven, R. What is protective space? Reconsidering niches in transitions to sustainability. Res. Policy 2012, 41, 1025-1036.

28. Geels, F.W. Regime Resistance against low-carbon transitions: Introducing politics and power into the multi-level perspective. Theorycult. Soc. 2014, 31, 21-40. [CrossRef]

29. Law, J. Technology and Heterogeneous Engineering: The Case of Portuguese Expansion. In The Social Construction of Technological Systems: New Directions in the Sociology and History of Technology; Cambridge University Press: Cambridge, UK, 1987; pp. 1-134.

30. Sengers, F. Mobility Transitions in a Multi-level Perspective. In: IDEAS IN MOTION. Theorizing Mobility Transitions. An Interdisciplinary Conversation. Transfers 2019, 7, 113-129.

31. Lasswell, H.D. Politics: Who Gets What, When, How; Pickle Partners Publishing: Cleveland, NY, USA, 1936.

32. Henderson, J. Street Fight: The Politics of Mobility in San Francisco; University of Massachusetts Press: Amherst, MA, USA, 2013.

33. Cresswell, T. Towards a politics of mobility. Environ. Plan. D Soc. Space 2010, 28, 17-31. [CrossRef]

34. Paterson, M. Automobile Politics: Ecology and Cultural Political Economy; Cambridge University Press: Cambridge, UK, 2007.

35. Buehler, R.; Pucher, J.; Altshuler, A. Vienna's Path to Sustainable Transport. Int. J. Sustain. Transp. 2016, 11, 257-271. [CrossRef]

36. Gössling, S. Urban Transport Transitions: Copenhagen, City of Cyclists. J. Transp. Geogr. 2013, 33, $196-206$. [CrossRef] 
37. Oldenziel, R.; de la Bruheze, A.A. Contested spaces: Bicycle Lanes in Urban Europe 1900-1995. Transf. Interdiscip. Rev. Mobil. Stud. 2011, 1, 29-49.

38. Oldenziel, R.; Emmanuel, M.; dela Bruheze, A.A.; Veraart, F. (Eds.) Cycling Cities: The European Experience; Foundation for the History of Technology: Eindhoven, The Netherlands, 2016.

39. Brand, U.; Wissen, M. What Kind of Great Transformation? The Imperial Mode of Living as a Major Obstacle to Sustainability Politics. GAIA 2018, 27, 287-292. [CrossRef]

40. Zimmer, W.; Blanck, R.; Bergmann, T.; Mottschall, M.; von Waldenfels, R.; Cyganski, R.; Wolfermann, A.; Winkler, C.; Heinrichs, M.; Dünnebeil, F.; et al. Endbericht Renewbility III-Optionen einer Dekarbonisierung des Verkehrssektors. 2016. Available online: http://www.renewbility.de/wp-content/uploads/Renewbility_II I_Endbericht.pdf (accessed on 1 September 2020).

41. Becker, H.; Ciari, F.; Axhausen, K. Measuring the car ownership impact of free-floating car-sharing-A case study in Basel, Switzerland. Transp. Res. Part D Transp. Environ. 2018, 65, 51-62. [CrossRef]

42. Shaheen, S.; Cohen, A.; Zohdy, I. Shared Mobility: Current Practices and Guiding Principles (No. FHWA-HOP-16-022); Federal Highway Administration: Washington, DC, USA, 2016.

43. Kopp, J.; Gerike, R.; Axhausen, K.W. Do Sharing People Behave Differently? An Empirical Evaluation of the Distinctive Mobility Patterns of Free-Floating Car-Sharing Members. Transportation 2015, 42, 449-469. [CrossRef]

44. Hülsmann, F.; Wiepking, J.; Zimmer, W.; Hacker, F.; Kasten, P.; Schmolck, B.; Schönau, M.; Waldenfels, R.; Sunderer, G.; Götz, K.; et al. Share -Wissenschaftliche Begleitforschung zu car2go mit Batterieelektrischen und Konventionellen Fahrzeugen; Öko-Insitut/ISOE-Institut für Sozial-Ökologische Forschung: Berlin/Frankfurt am Main, Germany, 2018.

45. Ma, X.; Yuan, Y.; Van Oort, N.; Hoogendoorn, S. Bike-sharing systems' impact on modal shift: A case study in Delft, the Netherlands. J. Clean. Prod. 2020, 259, 120846. [CrossRef]

46. Fischman, E. Bikeshare: A Review of Recent Literature. Transp. Rev. 2016, 36, 92-113. [CrossRef]

47. City of Portland: 2018 E-Scooter Findings Report. Available online: https://www.portlandoregon.gov/trans portation/78431 (accessed on 1 September 2020).

48. Krier, C.; Chrétien, J.; Louvet, N. Usages et Usagers de Services de Trottinettes Électriques en Free-Floating en France. Available online: https://6-t.co/trottinettes-freefloating/ (accessed on 1 September 2020).

49. Hollingsworth, J.; Copeland, B.; Johnson, J.X. Are e-scooters polluters? The environmental impacts of shared dockless electric scooters. Environ. Res. Lett. 2019, 14, 084031.

50. Jittrapirom, P.; Caiati, V.; Feneri, A.; Ebrahimigharehbaghi, S.; Alonso González, M.J.; Narayan, J. Mobility as a Service: A critical review of definitions, assessments of schemes, and key challenges. Urban Plan. 2017, 2, $13-25$.

51. Utriainen, R.; Pöllänen, M. Review on Mobility as a Service in scientific literature. In Proceedings of the 1st International Conference on Mobility as a Service (ICoMaaS), Tampere, Finland, 28-29 November 2017.

52. Lyons, G. Getting smart about urban mobility-Aligning the paradigms of smart and sustainable. Transp. Res. Part A Policy Pract. 2018, 115, 4-14. [CrossRef]

53. Brand, U.; Welzer, H. Alltag und Situation. Soziokulturelle Dimensionen sozial-ökologischer Transformation. Transform. Bd. 2019, 28, 313-332.

54. Groth, S. Multioptionalität. Ein neuer ("alter") Terminus in der Alltagsmobilität der modernen Gesellschaft? Raumforsch. Und Raumordn. 2019, 77, 17-34. [CrossRef]

55. Nobis, C.; Kuhnimhof, T. Mobilität in Deutschland-MiD Ergebnisbericht. Studie von Infas, DLR, IVT und Infas 360 im Auftrag des Bundesministers für Verkehr und Digitale Infrastruktur (FE-Nr. 70.904/15). 2018. Available online: http://www.mobilitaet-in-deutschland.de/pdf/MiD2017_Ergebnisbericht.pdf (accessed on 1 September 2020).

56. Schwedes, O. The Field of Transport Policy: An Initial Approach. Ger. Policy Stud. 2011, 7, 7-41.

57. Statista: Bestand an Personenkraftwagen in Berlin von 2008 bis 2020. Available online: https://de.statista.co m/statistik/daten/studie/255179/umfrage/bestand-an-pkw-in-berlin/ (accessed on 1 September 2020).

58. Destatis: Automobilindustrie: Deutschlands wichtigster Industriezweig mit Produktionsrückgang um 7,1 \% im 2. Halbjahr 2018, Pressemitteilung Nr. 139 vom 9. April 2019. Available online: https://www.destatis.de/ DE/Presse/Pressemitteilungen/2019/04/PD19_139_811.html (accessed on 1 September 2020).

59. Brunnengräber, A.; Haas, T. (Eds.) Baustelle Elektromobilität: Sozialwissenschaftliche Perspektiven auf die Transformation der (Auto-) Mobilität (Vol. 95); Transcript: Bielefeld, Germany, 2020. 
60. Hermann, A.; Klinski, S.; Heyen, D.A.; Kasten, P. Rechtliche Hemmnisse und Innovationen für eine nachhaltige Mobilität-untersucht an Beispielen des Straßenverkehrs und des Öffentlichen Personennahverkehrs in Räumen schwacher Nachfrage; Umweltbundesamt: Dessau-Roßlau, Germany, 2019. Available online: https://www.umweltbundesamt.de/sites/default/files/medien/1410/publikationen/2019-08 -20_texte_94-2019_rechtsinnmobil_1-teilbericht-recht-innovation_0.pdf (accessed on 1 September 2020).

61. Notz, J.N. Die Privatisierung Öffentlichen Raums Durch Parkende Kfz. Von der Tragödie Einer Allmende - ̈̈̈ber Ursache, Wirkung und LEGITIMATION Einer Gemeinwohlschädigenden Regulierungspraxis; IVP-Discussion Paper; Technische Universität Berlin: Berlin. Germany, 2017.

62. Bracher, T.; Bührmann, S.; Hanke, S.; Hertel, M.; Weber, T. Grundlegender Änderungsbedarf im Straßen- und Straßenverkehrsrecht. Anforderungen des Radverkehrs und Änderungsvorschläge, Sonderberichte; Deutsches Institut für Urbanistik: Berlin, Germany, 2018.

63. Association of German Cities (Deutscher Städtetag) Sustainable Urban Mobility for all. Agenda for a Mobility Transition from Municipal Stand Point. A position Paper by the Association of German Cities. 2018. Available online: http://www.staedtetag.de/imperia/md/content/dst/veroeffentlichungen/mat/popa_sustain able_urban_mobility_for_all_web.pdf (accessed on 1 September 2020).

64. Haefeli, U. Verkehrspolitik und urbane Mobilität: Deutsche und Schweizer Städte im Vergleich 1950-1990; Universität Bern, zugl. Habil.-Schrift 2006; Steiner: Stuttgart, Germnay, 2008.

65. Schwedes, O.; Ruhrort, L.; Länderverkehrspolitik; Hildebrandt., A.; Wolf, F. Die Politik der Bundesländer. In Zwischen Föderalismusreform und Schuldenbremse; Springer: Wiesbaden, Germany, 2016; pp. 209-232.

66. Frehn, M.; Aichinger, W.; Spott, M.; Weiß, M. Konzepte für den Stadtverkehr der Zukunft, BBSR-Online-Publikation. 2019. Available online: https://d-nb.info/1187955124/34 (accessed on 1 September 2020).

67. SenUVK Berlin 2020: Berliner Mobilitätsgesetz. Available online: https://www.berlin.de/senuvk/verkehr/m obilitaetsgesetz/ (accessed on 1 September 2020).

68. Götting, K.; Becker, S. Reaktionen auf die Pop-Up-Radwege in Berlin Ergebnisse Einer Explorativen Umfrage zur Temporären Radinfrastruktur im Kontext der Covid-19 Pandemie; IASS/TU Berlin: Potsdam/Berlin, Germany, 2020.

69. Agora Verkehrswende. E-Tretroller im Stadtverkehr. Handlungsempfehlungen für Deutsche Städte und Gemeinden zum Umgang mit Stationslosen Verleihsystemen. 2019. Available online: https://www.agora-verkehrswende.de/fileadmin/Projekte/2019/E-Tretroller_im_Stadtverkehr/Agora-Verk ehrswende_e-Tretroller_im_Stadtverkehr_WEB.pdf (accessed on 1 September 2020).

70. Koschmieder, N.; Huß, F. E-Scooter. Regulatorische Herausforderung für Kommunen? Die Öffentl. Verwalt. 2020, 3, 81-91.

71. City of Leipzig 2020: E-Scooter in Leipzig. Wichtige Informationen für Verleiher. Available online: https: //www.leipzig.de/umwelt-und-verkehr/unterwegs-in-leipzig/e-scooter/ (accessed on 1 September 2020).

72. City of Düsseldorf 2019: Stadt Will E-Scooter-Verleiher Stärker in die Pflicht Nehmen. Available online: https://www.duesseldorf.de/aktuelles/news/detailansicht/newsdetail/stadt-will-e-scoo ter-verleiher-staerker-in-die-pflicht-nehmen-1.html (accessed on 1 September 2020).

73. Wissenschaftlicher Dienst (Wissenschaftliche Dienste des Deutschen Bundestages) 2020: E-Scooter. Gemeingebrauch oder Sondernutzung? Ausarbeitung WD3-3000-063/20. Available online: https://www.bund estag.de/resource/blob/693762/918c7310444ff7be42b17a0cd310c541/WD-3-063-20-pdf-data.pdf (accessed on 1 September 2020).

74. Berlin.de 2020: Einrichtung Weiterer E-Scooter-Stellplätze. Available online: https://www.berlin.de/ba-fried richshain-kreuzberg/aktuelles/bezirksticker/2020/einrichtung-weiterer-e-scooter-stellplaetze-967992.php2 020 (accessed on 1 September 2020).

75. Neumann, P. Versprochene Parkplätze für E-Scooter Lassen Auf Sich Warten, Berliner Zeitung, 29.6.2020. Available online: https://www.berliner-zeitung.de/mensch-metropole/versprochene-parkplaetze-fuer-e-sco oter-lassen-auf-sich-warten-li.90362 (accessed on 1 September 2020). 
76. Westphal, T. Ein Jahr Multimodale Mobilität: Jelbi zieht Bilanz, Movinc, 28 June 2020. Available online: https://movinc.de/bus-bahn/jelbi-zieht-bilanz/ (accessed on 1 September 2020).

77. ITF (International Transport Forum): The Shared-Use City. Managing the Curb. 2018. Available online: https: //www.itf-oecd.org/sites/default/files/docs/shared-use-city-managing-curb_3.pdf (accessed on 1 September 2020).

(C) 2020 by the author. Licensee MDPI, Basel, Switzerland. This article is an open access article distributed under the terms and conditions of the Creative Commons Attribution (CC BY) license (http://creativecommons.org/licenses/by/4.0/). 